\title{
Factors Affecting Entrepreneurial Opportunity Recognition Among Food and Beverage SMEs
}

\author{
Lydiawati Soelaiman $^{1 *}$, Liediana Liediana ${ }^{1}$
}

\author{
${ }^{1}$ Faculty of Economics and Business, Universitas Tarumanagara, West Jakarta, DKI Jakarta, Indonesia, 11470 \\ *Corresponding author. Email: lydiawatis@fe.untar.ac.id
}

\begin{abstract}
The growth of Food and Beverage (F\&B) SMEs continues to increase along with the interest of Indonesian people in enjoying the ready-to-eat food. SMEs in this field must possess entrepreneurial alertness to seek, realize and recognize opportunities, also known as entrepreneurial opportunity recognition. This study aimed to determine the impacts of: 1) social network on entrepreneurial alertness, 2) prior knowledge on entrepreneurial alertness, 3) self-efficacy on entrepreneurial alertness, 4) entrepreneurial alertness on entrepreneurial opportunity recognition among F\&B SMEs in Jakarta. This study used purposive sampling technique and a sample consisting of $80 \mathrm{~F} \& \mathrm{~B}$ SMEs was obtained. The results proved that social network, prior knowledge, and self-efficacy have positive and significant impacts on entrepreneurial alertness. Likewise, entrepreneurial alertness has a positive and significant impact on entrepreneurial opportunity recognition. This is an aspect that F\&B SMEs need to pay attention to in order to identify, see, recognize, and find the opportunities, which then generate the potential ideas to compete in the market.
\end{abstract}

Keywords: social network, prior knowledge, self-efficacy, entrepreneurial alertness, entrepreneurial opportunity recognition

\section{INTRODUCTION}

The food and beverage industry is projected to boost the Gross Domestic Product (GDP) growth with contribution to GDP reaching 19.87 percent in the second quarter of 2020 [1]. SMEs in this field are growing, developing, and continuing to experience growth due to the habits of Indonesian people, especially in Jakarta, who prefer to enjoy the ready-to-eat food.

In the efforts to build and develop a business, an entrepreneur certainly must be able to find, recognize, and realize the opportunities that exist in the Food and Beverage (F\&B) business. A person's ability to recognize opportunities by seeing and observing changes in environmental conditions is called entrepreneurial opportunity recognition [2]. One among the key factors in the opportunity recognition process is entrepreneurial alertness, which is how someone can identify the opportunities whereas other people may not see them [3]. Entrepreneurial alertness is needed by entrepreneurs, because someone who is aware, sensitive, and alert to environmental changes and their signs will have a higher possibility to recognize the opportunities in their business [4].

Entrepreneurial alertness is also greatly influenced by the relationship between individuals through their social network. Social network consists of a series of relationships among the groups of people who have business and personal relationships with the same interests [5]. Through social network, individual reach is greater and the potential to find opportunities is higher. The opportunity recognition process can be developed through three social network activities such as information gathering, thinking through discussion with other people, and resource assembling at assessment. Thus, one must have a strong social network to identify opportunities, because through this interaction, the information can be shared, which then stimulates the growth of creative thinking in finding and recognizing those opportunities [6]. The wider the social network one has, the higher the entrepreneurial alertness will be towards opportunities with the potential to succeed [7].

Apart from the social network, another factor that can give a rise to entrepreneurial alertness is prior knowledge. Prior knowledge is considered as an important factor and has a competitive advantage in identifying opportunities, because in certain fields it allows one to gain significant advantage [8]. Prior knowledge becomes an important source of innovation in growing and sustaining business as well as increasing its competitiveness [9]. Prior knowledge can influence someone to find, connect the information, and help in making decisions, because one has the knowledge related to the market, customers, and customer problems with the intention of knowing how to meet the consumers' needs [10]. Prior knowledge plays an important role, 
because it can act as a guide, a cue, and improve alertness and become more sensitive to new information and opportunities [11].

Not only social network and prior knowledge, self-efficacy factors are also considered to be important factors that can affect entrepreneurial alertness. Self-efficacy is a person's belief in his/her ability to carry out certain tasks in his/her own way, meaning that someone who does not have selfefficacy will miss the opportunities [12]. Someone with high self-efficacy is more able to realize opportunity alertness and to evaluate these opportunities more precisely [13].

This study aimed to test empirically whether there is an influence of social network, prior knowledge, and selfefficacy on entrepreneurial alertness. In addition, this study was also conducted to analyze whether there is an influence of entrepreneurial alertness on entrepreneurial opportunity recognition among F\&B SMEs in Jakarta. The results of this study are expected to be useful for SMEs in F\&B business in order to find the opportunities by paying attention to wider social network, utilizing prior knowledge to better understand customers and market needs, and increasing self-efficacy to be more confident in recognizing those opportunities.

\section{LITERATURE REVIEW AND HYPOTHESIS}

\subsection{Social network}

Social network is a set of relationships among a group of "actors" (the "actors" can be individuals, departments, and others) who tend to have similar interest [5]. Another study stated that social network is an individual's interpersonal network, including the weak-tie and strong-tie network, which facilitate the access to diverse information that benefits from the learning and information dissemination processes in order to further discover the opportunities [14]. Based on several definitions above, it is concluded that a social network is an access that contains information and connections with outsiders that encourage an entrepreneur to develop opportunities in his/her business.

\subsection{Prior knowledge}

Individuals having prior knowledge can be more focused on the main aspects of existing information, and process it more efficiently, thus resulting in more opportunity identification [15]. Besides, prior knowledge refers to an individual's distinctive information about a particular subject that can be the result of work experience, education, and others. With the accumulated information and knowledge acquired from life experiences, some people may establish the connection in order to recognize the opportunity as long as it is related to their available information [16]. From the explanation above, prior knowledge can be concluded as the knowledge that individuals possess regarding certain information and subjects so that they can make connections to recognize and identify the opportunities.

\subsection{Self-efficacy}

Self-efficacy is defined as entrepreneurs' primary beliefs that they can recognize the entrepreneurial opportunities, take actions, and create conditions that permit business startup or innovation [17]. Another definition of selfefficacy is a person's ability to make decision from opportunity identification by preventing greater risk, because the person is aware of his / her own ability. [18] Based on those definitions, self-efficacy can be concluded as the belief of a person or individual about his / her ability to do and complete a certain job well.

\subsection{Entrepreneurial alertness}

Entrepreneurial alertness as awareness can be defined as a tendency to notice and be sensitive to information regarding the objects, incidents, and patterns of behavior in the environment. It is argued that high alertness can increase the tendency of an opportunity being recognized [19]. Another study stated that entrepreneurial alertness is viewed as conceptually distinct from the opportunity's subsequent development, and from the activities undertaken to subsequently exploit it [11]. Based on the such definition, entrepreneurial alertness can be concluded as one's sensitivity to see opportunities found in the entrepreneurial process which may not be seen by others.

\subsection{Entrepreneurial opportunity recognition}

Entrepreneurial opportunity recognition can be perceived as the cognitive process through which an individual concludes that he / she has identified an opportunity [2]. Besides, entrepreneurial opportunity recognition can also be defined as a type of recognition regarding the environmental threats and opportunities in the industry as well as general business environment [20]. Based on several descriptions above, it can be concluded that entrepreneurial opportunity recognition is a process in which an individual has the ability to identify, see, recognize, and find the opportunities and then generate new business ideas that are potentially profitable.

\subsection{The impact of social network on entrepreneurial alertness}

Social network and entrepreneurial alertness have a positive and significant relationship [6]. Social network are important, because they form relationships among other people who can share the information and stimulate creative thinking regarding potential opportunities. In order to find 
the strong entrepreneurial opportunities, one must have social relationships and improve his/her entrepreneurial awareness [21]. Based on the description above, this research hypothesis related to social network and entrepreneurial alertness can be developed as follow:

$\mathrm{H}_{1}$ : Social Network has a positive and significant impact on Entrepreneurial Alertness

\subsection{The impact of prior knowledge on entrepreneurial alertness}

A previous study revealed that prior knowledge about the market and customer problems has a positive impact on entrepreneurial alertness, in a way that prior knowledge and experience in some contexts can result in an increase in individual's cognitive abilities [22]. Based on the phenomenon, this research hypothesis related to prior knowledge and entrepreneurial alertness can be developed as follow:

$\mathrm{H}_{2}$ : Prior Knowledge has a positive and significant impact on Entrepreneurial Alertness

\subsection{The impact of self-efficacy on entrepreneurial alertness}

Individuals with higher levels of self-efficacy will be more likely to be aware of new opportunities, whereas entrepreneurs who are alert will tend to pursue the opportunities continuously [2]. Based on the phenomenon, this research hypothesis related to self-efficacy and entrepreneurial alertness can be developed as follow:

$\mathrm{H}_{3}$ : Self-Efficacy has a positive and significant impact on Entrepreneurial Alertness

\subsection{The impact of entrepreneurial alertness on entrepreneurial opportunity recognition}

Entrepreneurial alertness is a cognitive ability which allows a person to seek, connect, evaluate, and assess the information from various fields in order to help identify the opportunities [3]. Based on the definition, this research hypothesis related to entrepreneurial alertness and entrepreneurial opportunity recognition can be developed as follow:

H4: Entrepreneurial Alertness has a positive and significant impact on Entrepreneurial Opportunity Recognition

Based on the explanation on the relationships among these variables, the research model used in this study can be developed as follow:

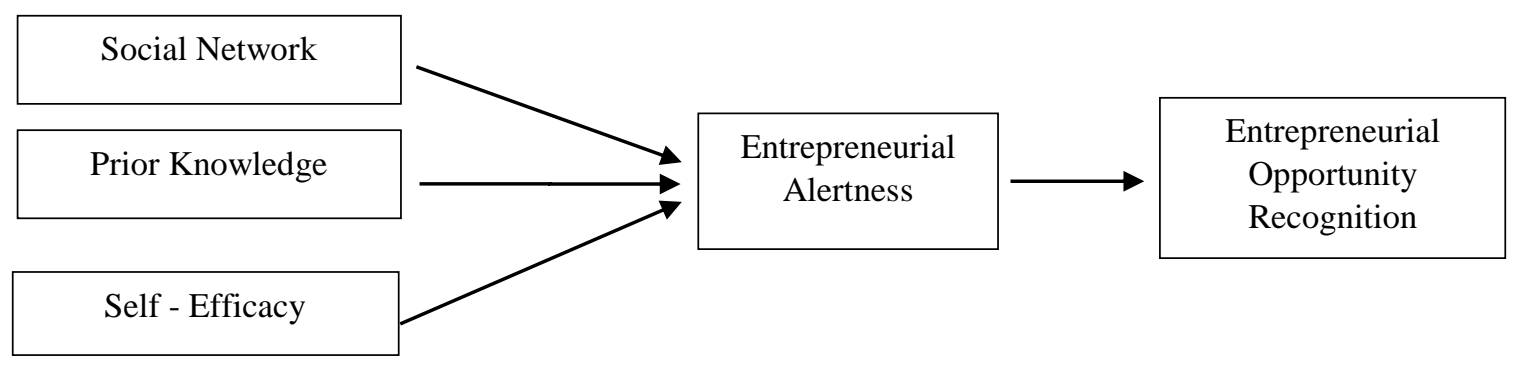

Figure 1 Research model

\section{RESEARCH METHOD}

This study used a cross-sectional method by conducting one-time data collection with purposive sampling technique, which is a sampling technique based on certain considerations or criteria in order to provide the appropriate information needed by the researcher. The sample amounted to 80 respondents, the majority of whom were male $(62.7 \%)$, with most of them were between 21 years 26 years old $(61 \%)$, and based on the latest education most respondents were undergraduates $(57.5 \%)$.

All data obtained was then analyzed using the PLS-SEM model with SmartPLS tool. There were 17 indicators used in this study, consisting of 3 indicators of Social Network variables, 3 indicators of Prior Knowledge variables, 4 indicators of Self-Efficacy, 4 indicators of Entrepreneurial Alertness, and 3 indicators of Entrepreneurial Opportunity
Recognition [6][21]. The instrument used in this study was questionnaire using a 5-point Likert scale ranging from "Strongly Disagree", to "Strongly Agree". After analyzing the validity and reliability, one item was removed from the total of 17 items, because the loading factor of the indicator was less than 0.5 .

\section{RESULT AND DISCUSSION}

After making adjustments to meet the loading factor criteria, the 16 items had an AVE greater than 0.5 and a loading factor greater than 0.5 . Thus, they met the criteria for convergent validity. Furthermore, the results of the reliability analysis showed that all variables met the reliability requirements with composite reliability greater than 0.7 . The results of validity and reliability test are described in Table 1 and Table 2. 
Table 1 Convergent Validity and Reliability

\begin{tabular}{|c|c|c|c|c|}
\hline Variable & Item & Loading Factor & AVE & Composite Reliability \\
\hline \multirow{3}{*}{ Social Network } & SN1 & 0.744 & \multirow{3}{*}{0.609} & \multirow{3}{*}{0.824} \\
\hline & SN2 & 0.794 & & \\
\hline & SN3 & 0.802 & & \\
\hline \multirow{3}{*}{ Prior Knowledge } & PK1 & 0.700 & \multirow{3}{*}{0.515} & \multirow{3}{*}{0.760} \\
\hline & PK2 & 0.802 & & \\
\hline & PK3 & 0.641 & & \\
\hline \multirow{4}{*}{ Self-efficacy } & SE1 & 0.863 & \multirow{4}{*}{0.712} & \multirow{4}{*}{0.908} \\
\hline & SE2 & 0.895 & & \\
\hline & SE3 & 0.867 & & \\
\hline & SE4 & 0.741 & & \\
\hline \multirow{3}{*}{$\begin{array}{c}\text { Entrepreneurial } \\
\text { Alertness }\end{array}$} & EA2 & 0.896 & \multirow{3}{*}{0.683} & \multirow{3}{*}{0.865} \\
\hline & EA3 & 0.867 & & \\
\hline & EA4 & 0.702 & & \\
\hline \multirow{3}{*}{$\begin{array}{c}\text { Entrepreneurial } \\
\text { Opportunity } \\
\text { Recognition }\end{array}$} & EOR1 & 0.585 & \multirow{3}{*}{0.521} & \multirow{3}{*}{0.762} \\
\hline & EOR2 & 0.848 & & \\
\hline & EOR3 & 0.709 & & \\
\hline
\end{tabular}

Table 2 Discriminant Validity (Fornell-Larcker)

\begin{tabular}{|c|c|c|c|c|c|}
\hline & $\begin{array}{c}\text { Entrepreneurial } \\
\text { Alertness }\end{array}$ & $\begin{array}{c}\text { Entrepreneurial } \\
\text { Opportunity } \\
\text { Recognition }\end{array}$ & $\begin{array}{c}\text { Prior } \\
\text { Knowledge }\end{array}$ & Self-Efficacy & $\begin{array}{c}\text { Social } \\
\text { Network }\end{array}$ \\
\hline $\begin{array}{c}\text { Entrepreneurial } \\
\text { Alertness }\end{array}$ & 0.826 & & & & \\
\hline $\begin{array}{c}\text { Entrepreneurial } \\
\text { Opportunity } \\
\text { Recognition }\end{array}$ & 0.509 & 0.722 & & & \\
\hline Prior Knowledge & 0.519 & 0.472 & 0.718 & & \\
\hline Self-Efficacy & 0.513 & 0.341 & 0.407 & 0.844 & \\
\hline Social Network & 0.451 & 0.367 & 0.283 & 0.198 & 0.780 \\
\hline
\end{tabular}

Furthermore, the path coefficient test was conducted to determine whether the independent variable partially has a significant impact on the dependent variable. The following are the results of the hypothesis test using the bootstrapping method:

Table 3 Path Coefficient Analysis Result

\begin{tabular}{|c|c|c|c|}
\hline Hypothesis & Path Coefficient & P-Values & Result \\
\hline $\begin{array}{c}\mathrm{H}_{1}: \text { Social Network } \rightarrow \text { Entrepreneurial } \\
\text { Alertness }\end{array}$ & 0.301 & 0.002 & Supported \\
\hline $\begin{array}{c}\mathrm{H}_{2}: \text { Prior Knowledge } \rightarrow \text { Entrepreneurial } \\
\text { Alertness }\end{array}$ & 0.299 & 0.002 & Supported \\
\hline H3 $_{3}:$ Self-Efficacy $\rightarrow$ Entrepreneurial Alertness & 0.332 & 0.001 & Supported \\
\hline $\begin{array}{c}\text { H }_{4}: \text { Entrepreneurial Alertness } \rightarrow \\
\text { Entrepreneurial Opportunity Recognition }\end{array}$ & 0.509 & 0.000 & Supported \\
\hline
\end{tabular}


Based on the results of path coefficient test in Table 3, it can be concluded that entrepreneurial alertness has the largest coefficient on entrepreneurial opportunity recognition (0.509). Meanwhile, the entrepreneurial alertness variable is most influenced by the self-efficacy variable, which has a coefficient of 0.332 , and then followed by social network with a coefficient of 0.301 and prior knowledge variable which has a coefficient of 0.299 . The results in Table 3 can also prove that $\mathrm{H}_{1}, \mathrm{H}_{2}, \mathrm{H}_{3}$, and $\mathrm{H}_{4}$ were supported.

The result of first hypothesis testing showed that social network positively and significantly affects entrepreneurial alertness $\left(\mathrm{H}_{1}\right)$. The result of this study is in line with a study conducted by [6] stating that there is a positive and significant influence of social network on entrepreneurial alertness. In order to find and identify the opportunities, one must have social network in order to increase the entrepreneurial alertness [21]. Social network is important for $\mathrm{F} \& \mathrm{~B}$ SMEs to improve the access to information obtained through the interactions with customers, suppliers, work partners and non-work partners, which will make entrepreneurs become more sensitive. Any information can create creative and unique thoughts that can directly assist in finding opportunities in order to develop the business.

Furthermore, the hypothesis testing on the prior knowledge variable towards entrepreneurial alertness showed that prior knowledge positively and significantly affects entrepreneurial alertness $\left(\mathrm{H}_{2}\right)$. Prior knowledge plays an important role in developing entrepreneurial alertness, because entrepreneurs can use it to adapt to various environmental changes with various potential opportunities [11]. Prior knowledge can be obtained by F\&B business owners through suggestions and criticism from consumers. This makes entrepreneurs become more sensitive to opportunities in determining what customers desire.

The hypothesis testing on self-efficacy variable towards entrepreneurial alertness in this study showed a positive and significant impact $\left(\mathrm{H}_{3}\right)$. Individuals with a higher selfefficacy are more likely to be aware of new opportunities and may tend to pursue the opportunities continuously [2]. Self-efficacy is important for F\&B SME entrepreneurs, because high self-efficacy can help them find, develop, and run their business, which then leads to the increase in entrepreneurial alertness.

Based on the result of the fourth hypothesis testing, it can be known that entrepreneurial alertness has a positive and significant effect on entrepreneurial opportunity recognition $\left(\mathrm{H}_{4}\right)$. Entrepreneurial alertness is a cognitive ability that allows someone to seek, connect, evaluate, and assess information from various fields to help in entrepreneurial opportunity recognition [3]. F\&B SME entrepreneurs with high alertness will become more sensitive in finding opportunities, making it possible to find and evaluate information, leading to the increased entrepreneurial opportunity recognition of which others may not be aware.

\section{CONCLUSION AND IMPLICATION}

From the results obtained in this study, it can be concluded that Social Network, Prior Knowledge and Self Efficacy play positive and significant roles in Entrepreneurial Alertness among F\&B SMEs. These entrepreneurs need to establish good social network, pay attention to suggestions provided by consumers, and learn many things in order to motivate them to find new opportunities in their business. In addition, the results of this study also conclude that Entrepreneurial Alertness plays a positive and significant effect on Entrepreneurial Opportunity Recognition. This is in accordance with the factors affecting the process theory, which describes that every opportunity recognized by an entrepreneur will be preceded by a high state of alertness to information.

Based on these conclusions, the F\&B SME entrepreneurs who are running their businesses need to pay attention to the social network that have been established with customers, suppliers, work partners, and other business relations, in order to reach a wider network and share the information, in order to be able to identify and find opportunities for their business development. SMEs must also take advantages of prior knowledge and experience in running a business to better understand the customers' needs and find the solutions. It is also important for entrepreneurs to have the motivation to develop selfefficacy so that they become more confident in finding opportunities to develop their business.

\section{LIMITATION AND SUGGESTION}

The researchers are aware that there are many limitations when conducting this study. One of them is that this research was conducted during the COVID-19 pandemic, and due to the Large-Scale Social Distancing policy and self-quarantine suggested by the government, the data was collected by distributing Google Form to respondents. This led to the number of respondents being limited to $80 \mathrm{~F} \& \mathrm{~B}$ SME entrepreneurs in Jakarta. Suggestions for further research include: increase the number of samples and narrow down the type of food and/or beverage in order to strengthen the research results.

\section{REFERENCES}

[1] Arief, Andi M, Kuartal III/2020, Sektor Makanan \& Minuman jadi Penggerak Utama Industri Pengolahan, Bisnis.com, Retrieved September 29, 2020, from https://ekonomi.bisnis.com/read/20200805/257/127560 1/kuartal-iii2020-sektor-makanan-minuman-jadipenggerak-utama-industri-pengolahan 
[2] Baron, R. A., Opportunity recognition as pattern recognition: How entrepreneurs "connect the dots" to identify new business opportunities, Academy of Management Perspectives, 20(1), 2006, pp. 104-119. https://doi.org/10.5465/AMP.2006.19873412

[3] Tang, Jintong, Kacmar, K. Michele \& Busenitz, Lowell., Entrepreneurial alertness in the pursuit of new opportunities, Jounal of Business Venturing 27(1), 2012, pp. $77-94$.

https://doi.org/10.1016/j.jbusvent.2010.07.001

[4] Ardichvili, A., Cardozo, R., \& Ray, S., A theory of entrepreneurial opportunity identification and development, Journal of Business Venturing, 18(1), 2003, pp. 105 - 123. https://doi.org/10.1016/S08839026(01)00068-4

[5] Liebowitz, J., Social Networking: The Essence of Innovation, Scarecrow Press, 2007.

[6] Nikraftar, T., \& Hosseini, E., Factors affecting entrepreneurial opportunities recognition in tourism small and medium sized enterprises, Tourism Review, 71(1), 2016, pp. 6-17. https://doi.org/10.1108/TR-092015-0042

[7] De Koning, A. J., \& Muzyka, D. F., Conceptualizing Opportunity Recognition as a SocioCognitive Process, SSE/EFI Working Paper Series in Business Administration, Centre for Advanced Studies in Leadership and the Economic Research Institute, Stockholm School of Economics, Sweden, 1999(13), 1999

[8] Massa, S., \& Testa, S., A knowledge management approach to organizational competitive advantage: Evidence from the food sector, European Management Journal, 27(2), 2009, pp. 129-141. https://doi.org/10.1016/j.emj.2008.06.005

[9] Harris, R., McAdam, R., McCausland, I. and Reid, R., Knowledge management as a source of innovation and competitive advantage for SMEs in peripheral regions, International Journal of Entrepreneurship and Innovation, 14(1), 2013, pp. 49-61. https://doi.org/10.5367\%2Fijei.2013.0105

[10] Tang, J., \& Murphy, P. J., Prior knowledge and new product and service introductions by entrepreneurial firms: The mediating role of technological innovation, Journal of Small Business Management, 50(1), 2012, pp.41-62. https://doi.org/10.1111/j.1540-627X.2011.00343.x

[11] Valliere, D., Towards a schematic theory of entrepreneurial alertness. Journal of Business
Venturing, 28(3), 2013, pp. 430-442.

https://doi.org/10.1016/j.jbusvent.2011.08.004

[12] Bandura, A., Self-efficacy and health behaviour, in Baum, A., Newman, S., Wienman, J.,West, R. and McManus, R. (Eds), Cambridge Handbook of Psychology, Health and Medicine, Cambridge University Press, Cambridge, MA, 1997, pp. 160-162.

[13] Tang, Jintong, Environment Munificence for Entreprenuers: Entrepreneurial Alertness and Commitment, International Journal of Engreprenurial Behavior \& Research, 14(3), 2008, pp. 128-15. https://doi.org/10.1108/13552550810874664

[14] Busenitz, L., Shepherd, D., Nelson, T., Chandler, G., \& Zacharakis, A., Entrepreneurship in emergence: Past trends and future directions, Journal of Management, 29(3), 2003, pp. 285-308. https://doi.org/10.1016/S0149-2063(03)00013-8

[15] Shepherd, D. A., \& DeTienne, D. R., Prior knowledge, potential financial reward, and opportunity identification. Entrepreneurship: Theory and Practice, 29(1), 2005, pp. 91-112. https://doi.org/10.1111/j.15406520.2005.00071.x

[16] Lim, W., \& Xavier, R., Opportunity Recognition Framework: Exploring the Technology Entrepreneurs. American Journal of Economics, 5(2), 2015, pp. 105111. https://doi: 10.5923/c.economics. 201501.10

[17] Wilkerson, J. M., \& Wafa, M. A., Entrepreneurial Opportunity Recognition in a Declining City: Shrewd Choice or Wishful Thinking? Journal of Applied Business and Economics, 21(2), 2019, pp. 129-140. https://doi.org/10.33423/jabe.v21i1.1460

[18] Krueger, N., \& Dickson, P. R., How Believing in Ourselves Increases Risk Taking: Perceived SelfEfficacy and Opportunity Recognition. Decision Sciences, 25 (3), 1994, pp. 385-400. https://doi.org/10.1111/j.1540-5915.1994.tb00810.x

[19] Sheng-Tsung Hou., Antecedents and consequence of entrepreneurial alertness in Franchise chain, Proceedings of the 4th IEEE International Conference on Management of Innovation and Technology, Bangkok, 2008, pp.166-171 https://doi.org/ 10.1109/ICMIT.2008.4654356

[20] Krueger, N., Encouraging the identification of environmental opportunities, Journal of Organizational Change Management, 1(2), 1998, pp. 174-183. https://doi.org/10.1108/09534819810212151 
[21] Ozgen, E., \& Baron, R. A., Social sources of information in opportunity recognition: Impacts of mentors, industry network, and professional forums, Journal of Business Venturing, 22(2), 2007, pp. 174192. https://doi.org/10.1016/j.jbusvent.2005.12.001

[22] Hsieh, R.M., Kelley, D.J. and Liu, C.Y., The roles of entrepreneurial alertness, prior knowledge and social network in the process of opportunity recognition,

Frontiers of Entrepreneurship Research, 29(6), 2009, Article 12, available at

http://digitalknowledge.babson.edu/fer/vol29/iss6/12 